\title{
Local Secretion of Corticotropin-releasing Hormone in the Joints of Lewis Rats with Inflammatory Arthritis
}

\author{
Leslie J. Crofford, Hajime Sano, Katia Karalis, " Elizabeth L. Webster, * Ellen A. Goldmuntz, \\ George P. Chrousos, * and Ronald L. Wilder \\ Arthritis and Rheumatism Branch, National Institute of Arthritis and Musculoskeletal and Skin Diseases, and ${ }^{*}$ Developmental \\ Endocrinology Branch, National Institute of Child Health and Human Development, National Institutes of Health, Bethesda, \\ Maryland 20892
}

\begin{abstract}
Corticotropin-releasing hormone (CRH), the principal regulator of the hypothalamic-pituitary-adrenal axis, is also secreted in peripheral inflammatory sites, where it acts as a local proinflammatory agent. Arthritis-susceptible LEW/N rats have profoundly deficient hypothalamic CRH responses to inflammatory stimuli and other stressors. Arthritis-resistant F344/N rats, on the other hand, have a robust increase in hypothalamic CRH in response to the same stimuli. Contrasting with these hypothalamic CRH responses, we now show that CRH expression is markedly increased in the joints and surrounding tissues of $\mathrm{LEW} / \mathrm{N}$ rats with streptococcal cell wall- and adjuvant-induced arthritis, whereas it is not increased in similarly treated F344/N rats and is only transiently increased in congenitally athymic nude LEW.rnu/rnu rats. Glucocorticoid treatment suppressed, but did not eliminate, CRH immunoreactivity in the joints of $L E W / N$ rats. CRH mRNA was present in inflamed synovia, as well as in spinal cord, and inflamed synovia also expressed specific CRH-binding sites. We compared CRH expression in inflamed joints with another well-characterized proinflammatory neuropeptide, substance $P(S P)$, and found that SP immunoreactivity paralleled that of CRH. In summary, although $\mathrm{LEW} / \mathrm{N}$ rats have deficient hypothalamic $\mathrm{CRH}$ responses to inflammatory stimuli compared with $F 344 / N$ rats, they express relatively high levels of CRH at the site of inflammation. Analogous to SP, CRH may be delivered to the inflammatory site by peripheral nerves and/or synthesized at the inflammatory site. These data provide further support for the concept that CRH not only triggers the pituitary-adrenal antiinflammatory cascade, but also functions as an antithetically active local mediator of acute and chronic inflammatory arthritis. These data also illustrate the complex interrelationships of the nervous, endocrine, immune, and inflammatory systems. $(J$. Clin. Invest. 1992. 90:2555-2564.) Key words: neuropeptide • streptococcal cell wall arthritis $\bullet$ adjuvant arthritis $\bullet$ hypothalamic-pituitary-adrenal axis • substance $\mathbf{P} \bullet$ glucocorticoids
\end{abstract}

\section{Introduction}

The nervous, endocrine, immune, and inflammatory systems are intimately intertwined through overlapping regulatory me-

\footnotetext{
Address correspondence and reprint requests to Dr. Leslie J. Crofford, National Institutes of Health, Building 10, Room 9N240, 9000 Rockville Pike, Bethesda, MD 20892.

Received for publication 28 April 1992 and in revised form 15 July 1992.
}

The Journal of Clinical Investigation, Inc.

Volume 90, December 1992, 2555-2564 diator production and receptor expression. The hypothalamicpituitary-adrenal (HPA) ${ }^{1}$ axis exerts significant antiinflammatory effects, predominantly through glucocorticoid suppression of inflammatory cell recruitment, production and action of proinflammatory cytokines, and other mediators of inflammation. Corticotropin-releasing hormone ( $\mathrm{CRH}$ ), a 41-amino acid hypothalamic neuropeptide, is the major stimulus to pituitary production of ACTH, which in turn stimulates the production of glucocorticoids by the adrenal cortex. Our group recently investigated HPA axis responses to multiple inflammatory and noninflammatory stimuli in arthritis-susceptible Lewis (LEW/N) and relatively arthritis-resistant Fischer (F344/N) rat strains. LEW/N rats have a deficient hypothalamic CRH response to virtually all these stimuli, whereas $\mathrm{F} 344 / \mathrm{N}$ rats display robust increases in hypothalamic $\mathrm{CRH}$, with resultant differences in levels of plasma ACTH and corticosterone (1-5). Our group postulated that these differences in HPA axis responses play a role in the differing susceptibility of LEW/N and F344/N rats to experimentally induced inflammatory arthritis and other experimental autoimmune diseases (6-11).

Neuropeptides derived from peripheral nerves also play important roles in the expression of inflammatory reactions (12). For example, substance P (SP), which is primarily derived from sensory afferent unmyelinated $\mathrm{c}$ fibers, significantly augments the local inflammatory response (13-16). Many other neuropeptides are present in sensory afferent unmyelinated c and small myelinated A- $\delta$ fibers, but their contribution to inflammation remains less well defined. Capsaicin (8-methyl- $N$ vanillyl-6-nonenamide) causes selective depletion of neuropeptides or destruction of primary sensory neurons and has been shown to markedly decrease inflammation $(17,18)$. Immunoreactive $\mathrm{CRH}$ is present in the spinal cord and is also depleted by capsaicin treatment (19). Levine and colleagues (18, 20, 21 ) have demonstrated that both sensory afferent and sympathetic efferent nerve fibers contribute to the severity of inflammatory arthritis. Because CRH is localized to the dorsal sensory and sympathetic interomediolateral columns of the spinal cord $(19,22)$, as well as to the dorsal root and sympathetic ganglia $(23,24)$, it is reasonable to speculate that neuron-derived CRH, along with SP and other neuropeptides, contributes to the inflammatory process.

A growing body of data now support direct involvement of CRH in inflammation. $\mathrm{CRH}$ receptors are present on resident macrophages of mouse spleen (25) and human peripheral

1. Abbreviations used in this paper: $\mathrm{CRH}$, corticotropin-releasing hormone; HPA, hypothalamic-pituitary-adrenal; iCRH, immunoreactive CRH; ${ }^{125} \mathrm{I}-\mathrm{OCRH},{ }^{125} \mathrm{I}-\mathrm{Tyr}$-ovine $\mathrm{CRH}$; PCR, polymerase chain reaction; PPT, preprotachychinin; SCW, streptococcal cell wall; SP, substance $P$. 
blood lymphocytes and monocytes (26). Also, immunoreactive CRH (iCRH) and CRH mRNA are expressed in human peripheral blood leukocytes (27). CRH has direct in vitro effects on cells of the immune system, including stimulation of lymphocyte proliferation and expression of the interleukin-2 receptor $(28,29)$, stimulation of leukocyte secretion of interleukin-1 and interleukin-2 $(30,31)$, and induction of leukocyte-derived ACTH and $\beta$-endorphin (32). Lastly, our groups recently provided evidence that $\mathrm{CRH}$ is active locally in an in vivo rat model of acute inflammation. Carrageenin, a seaweedderived polysaccharide, produces a chemical inflammatory response when subcutaneously injected in rats. Immunoneutralization of $\mathrm{CRH}$ reduces both the volume and cellularity of the exudate in male Harlan-Sprague-Dawley rats, indicating that $\mathrm{CRH}$ has a predominantly proinflammatory effect. In this model, the antiinflammatory effect of anti-CRH antibody is equivalent to the antiinflammatory effect of anti-tumor necrosis factor- $\alpha$ antibody (33).

In the current study, we evaluate the hypothesis that CRH is locally expressed in inflammatory arthritis in the rat. We studied CRH expression in the joints of LEW/N, F344/N, and congenitally athymic nude LEW.rnu/rnu inbred rat strains after injection of streptococcal cell walls (SCW) or mycobacterial adjuvant. Because LEW/N rats have deficient hypothalamic CRH production, we were particularly interested in their ability to increase their peripheral iCRH in response to inflammation. Inflamed synovia were examined for the presence of CRH receptor-binding activity to assure the potential for local biological activity. Additionally, we examined synovial tissues, spleens, and spinal cords for CRH mRNA to identify the source of peripherally localized iCRH. To determine whether CRH was expressed similarly to other neuropeptides in the inflamed joint, we compared CRH expression with SP, a wellcharacterized proinflammatory neuropeptide, by immunohistochemistry and mRNA analysis. Because glucocorticoids downregulate hypothalamic $\mathrm{CRH}$ expression, we evaluated the effect of glucocorticoids on local expression of $\mathrm{iCRH}$.

\section{Methods}

Animals. 6-wk-old specific pathogen- and virus antibody-free LEW/N and F344/N female rats were obtained from Harlan Sprague Dawley, Inc. (Indianapolis, IN) and used for induction of SCW- and adjuvantinduced arthritis. Congenitally athymic nude LEW.rnu/rnu female rats were obtained from the Genetic Resource Section of the Veterinary Resources Program, National Center for Research Resources (Bethesda, MD). The animals were housed in microisolator cages and handled in laminar flow hoods. Animals were allowed free access to food and water during all experiments.

Induction of experimental polyarthritis. SCW peptidoglycan-polysaccharide fragments were prepared as previously described (34). A sterile aqueous suspension of sonicated SCW in PBS, pH 7.4, was administered by intraperitoneal injection at a dose equivalent to $20 \mu \mathrm{g}$ of rhamnose/g body weight. This dose has been previously determined to result, with $100 \%$ incidence, in acute and chronic polyarthritis in 6-wkold female LEW/N rats and acute, but not chronic, polyarthritis in athymic LEW.rnu/rnu rats. 6-wk-old female F344/N rats were also injected. Rats were killed at day 0 (uninjected) or at days 3 or 28 after injection.

Adjuvant arthritis was induced in arthritis-susceptible LEW/N rats by intradermal injection of $200 \mu \mathrm{l}$ of pulverized Mycobacterium butyricum (Difco Laboratories, Detroit, MI) at a concentration of $10 \mathrm{mg} / \mathrm{ml}$ in heavy paraffin oil at eight separate sites, four on each side, in the periscapular region with a 25-gauge needle, while the animals were under light anesthesia by $\mathrm{CO}_{2}$ narcosis. Athymic LEW.rnu/rnu and relatively arthritis-resistant $\mathrm{F} 344 / \mathrm{N}$ rats that usually do not develop clinically apparent arthritis were also injected as described. Animals were killed at day 0 (uninjected) or at days 4,10 , or 18 after injection. Hindfoot specimens were collected in $10 \%$ Formalin when the animals were killed, and then were decalcified in EDTA, embedded in paraffin, and sectioned at a thickness of $6 \mu \mathrm{m}$ onto gelatin-coated microscope slides.

Dexamethasone treatment of $S C W$-injected $L E W / N$ rats. A group of LEW/N rats injected with SCW was treated with glucocorticoids beginning on the day of injection (day 0 ). These animals received twice daily intraperitoneal injections of $1 \mathrm{ml}$ PBS alone or PBS plus dexamethasone 0.005 or $0.05 \mu \mathrm{g} / \mathrm{g}$ body weight. Animals were killed at day 3 after SCW injection. Hindfoot specimens were processed as above.

Immunohistochemistry. Rabbit polyclonal anti-CRH IgG was affinity purified by adsorption to and elution from a CRH-Sepharose 4B conjugate column containing $1 \mathrm{mg}$ of human/rat CRH 1-41 (Bachem California, Torrance, CA )/200 $\mu$ l of Sepharose (Sigma Chemical Co., St. Louis, MO). The sequences of human and rat CRH 1-41 are identical. The anti-CRH antiserum has cross-reactivity of $<0.001 \%$ for growth hormone-releasing hormone, antidiuretic hormone, ACTH, luteinizing hormone, follicle-stimulating hormone, thyroid-stimulating hormone, prolactin, $\beta$-endorphin, and growth hormone (35). Rabbit polyclonal anti-SP antibody was affinity purified as above by adsorption to and elution from an SP-Sepharose 4B conjugate column containing $1 \mathrm{mg}$ of synthetic SP (Sigma Chemical Co.). Tissue immunostaining was done with the Vectastain $\mathrm{ABC}$ kit (Vector Laboratories, Inc., Burlingame, $C A$ ) following the manufacturer's suggested protocol. For CRH and SP immunostaining, tissue sections were incubated in $0.3 \%$ peroxide in methanol for $20 \mathrm{~min}$, with diluted goat serum ( $1: 66.7)$ for $20 \mathrm{~min}$, and then in a humid chamber with either affinitypurified anti-CRH IgG, the anti-CRH IgG solution depleted of antiCRH antibody by adsorption on the $\mathrm{CRH}$-Sepharose conjugate column (affinity negative), affinity-purified anti-SP antibody, affinitynegative anti-SP antibody, or normal rabbit IgG (Jackson ImmunoResearch Laboratories, Inc., West Grove, PA) for $30 \mathrm{~min}$ at a concentration of $30 \mu \mathrm{g} / \mathrm{ml}$. The sections were then washed in PBS and incubated with biotinylated goat antisera to rabbit IgG for $30 \mathrm{~min}$. The sections were further washed in PBS and incubated with an avidin-DH/biotinylated horseradish peroxidase $\mathrm{H}$ complex (Vector Laboratories, Inc.) for $45 \mathrm{~min}$. Finally, the sections were washed and color was developed by immersion of the sections in a solution of 3,3'-diaminobenzidine tetrahydrochloride $(0.05 \% \mathrm{wt} / \mathrm{vol})$, nickel chloride $(0.04 \% \mathrm{wt} / \mathrm{vol})$, and hydrogen peroxide $(0.01 \%)$ in $50 \mathrm{mM}$ Tris $\mathrm{HCl}, \mathrm{pH} \mathrm{7.4,} \mathrm{for} \mathrm{2-5} \mathrm{min.}$ The sections were counterstained with light-green SF $(0.5 \%)$.

For each tissue specimen, the extent and intensity of staining with $\mathrm{CRH}, \mathrm{SP}$, or control antibodies were graded on a scale of 0 to $4+$ by a blinded observer on two separate occasions using coded slides. The observer assessed all tissues on each slide with particular attention to the histologic structures stained. A grade of $4+$ implies that staining of a tissue was maximally intense throughout the specimen, whereas $0 \mathrm{im}$ plies that staining was absent throughout the specimen. This methodology has been used extensively in earlier studies (36-38).

RNA preparation and analysis. Ankle synovia, spinal cords, and spleens were dissected from arthritic LEW/N rats on day 18 after adjuvant injection. Spinal cords and spleens were obtained from uninjected LEW/N rats, but we were unable to collect sufficient ankle synovia for RNA preparation from nonarthritic rats. Tissues for RNA extraction were minced, placed immediately into guanidine isothiocyanate buffer (4 M guanidine isothiocyanate, $25 \mathrm{mM}$ sodium citrate, $0.05 \%$ sodium lauryl sarcosine, and $0.1 \mathrm{M} \beta$-mercaptoethanol, $\mathrm{pH} 7.0$ ) on ice, homogenized, and then pelleted by centrifugation through a cesium chloride gradient (39).

For polymerase chain reaction (PCR) analysis of RNA, CDNA was prepared by reverse transcription of $5 \mu \mathrm{g}$ of each RNA sample in a $50-\mu 1$ reaction volume containing $50 \mathrm{mM}$ Tris- $\mathrm{HCl}$ ( $\mathrm{pH} \mathrm{8.3),} 40 \mathrm{mM} \mathrm{KCl}, 6$ $\mathrm{mM} \mathrm{MgCl}, 20 \mathrm{mM}$ dithiothreitol, $0.4 \mathrm{mM}$ each of dATP, dCTP, 
dGTP, and dGTP (Pharmacia Inc., Piscataway, $\mathrm{NJ}$ ), $2.4 \mathrm{ng} / \mu \mathrm{l}$ random hexamers (Perkin-Elmer Cetus Instruments, Norwalk, CT), $0.5 \mathrm{U} / \mu \mathrm{l}$ RNAse inhibitor (Perkin-Elmer Cetus Instruments), and $400 \mathrm{U} \mathrm{M-}$ MLV reverse transcriptase (Bethesda Research Laboratories, Gaithersburg, MD). The reaction mix was incubated at $37^{\circ} \mathrm{C}$ for $30 \mathrm{~min}$, diluted to $500 \mu \mathrm{l}$, and heated to $95^{\circ} \mathrm{C}$ for $10 \mathrm{~min}$. All PCR reactions were performed in a $50-\mu \mathrm{l}$ reaction volume containing $5 \mu \mathrm{l}$ of the cDNA mix in $50 \mathrm{mM} \mathrm{KCl}, 10 \mathrm{mM}$ Tris- $\mathrm{HCl}(\mathrm{pH} 8.3), 2 \mathrm{mM} \mathrm{MgCl}_{2}, 50 \mu \mathrm{M}$ each of dATP, dCTP, dGTP, and dTTP, $1 \mathrm{ng} / \mu \mathrm{l}$ each of sense and antisense primers, and $5 \mathrm{U}$ of Taq polymerase (Perkin-Elmer Cetus Instruments). Some reactions contained $5 \mu$ l of $\alpha-\left[{ }^{32} \mathrm{P}\right] \mathrm{dCTP} 3,000 \mathrm{Ci} /$ mmol (New England Nuclear-Dupont, Boston, MA). The primers used were, for rat CRH, sense 5'-CTC AGA GCC CAA GTA CGT TGA- $3^{\prime}$ and antisense $5^{\prime}$-TGC TCC GGT TGC AAG AAA TTC- 3 '; for rat $S P$ (preprotachykinin), sense 5'-AGA GGA AAT CGG TGC CAA CG-3' and antisense 5'-TTC GTA GTT CTG CAT TGC GC-3'; and for rat $\beta$-actin, sense $5^{\prime}$-ACC ACA GCT GAG AGG GAA ATC G-3' and antisense 5'-AGA GGT CTT TAC GGA TGT CAA CG-3'. All primer pairs amplified a fragment that crossed an intron, thereby distinguishing between $\mathrm{CDNA}$ and contaminating genomic DNA by the size of the expected fragment after amplification. The primers for SP (preprotachykinin) were designed to distinguish between the $\alpha, \beta$, and $\gamma$ forms of preprotachykinin mRNA, all of which can give rise to SP by posttranslational processing (40). The conditions for amplification were $95^{\circ} \mathrm{C}$ for $1 \mathrm{~min}, 60^{\circ} \mathrm{C}$ for $1 \mathrm{~min}$, and $72^{\circ} \mathrm{C}$ for $1 \mathrm{~min}$, continuing for 40 cycles when amplifying CRH or SP and 25 cycles when amplifying $\beta$-actin. Cycle curve studies between 20 and 40 cycles confirmed that, for the amounts of cDNA being amplified, the reactions had not reached the plateau of the amplification curve. Negative controls performed with no RNA added to the reverse transcription reaction or no reverse transcriptase yielded no detectable fragments with any primer pairs. The amplification reactions were analyzed either directly on a 5\% polyacrylamide gel (19:1 acrylamide/bisacrylamide) if they contained $\alpha-\left[{ }^{32} \mathrm{P}\right] \mathrm{dCTP}$ or were run on $1.5 \%$ agarose gels for Southern transfer.

For Southern blots, PCR reactions were transferred onto a nylon membrane (Nytran; Schleicher \& Schuell, Inc., Keene, NH). An antisense cRNA probe was prepared, using an RNA transcription kit (Stratagene, Inc., La Jolla, CA), from plasmid pBSrCRH1300 (a generous gift of Dr. Joseph A. Majzoub, Boston, MA) that contains a 700-nucleotide fragment encompassing the coding region of rat hypothalamic CRH mRNA (41). The membrane was hybridized in $50 \%$ formamide at $42^{\circ} \mathrm{C}$ for $24 \mathrm{~h}$ with $1.5 \times 10^{7} \mathrm{cpm}$ of the cRNA probe, and then washed twice for $20 \mathrm{~min}$ at $55^{\circ} \mathrm{C}$ in $0.1 \%$ sodium dodecyl sulfate, 15 $\mathrm{mM} \mathrm{NaCl}$, and $1.5 \mathrm{M}$ sodium citrate. The membrane was exposed to Kodak XAR film for 1 to $12 \mathrm{~h}$ at room temperature.

CRH-binding assay. The affinity and concentration of CRH-binding sites were determined from competitive displacement binding ex- periments in which rat synovial tissue homogenates and ${ }^{125} \mathrm{I}$-Tyr-ovine CRH ( ${ }^{125}$ I-oCRH) (New England Nuclear, Boston, MA) were incubated with increasing concentrations of rat/human CRH (Peninsula Laboratories, Inc., Belmont, CA ). Synovial tissues were dissected from the ankle joints of LEW/N rats on day 18 after adjuvant injection, frozen on dry ice, and stored at $-80^{\circ}$ until assayed. At the time of assay the frozen synovial tissues were weighed and then homogenized using a polytron (Brinkman Instruments, Inc., Westbury, NY) at a setting of 5 for $30 \mathrm{~s}$ in $20 \mathrm{vol}$ of ice-cold homogenization buffer $(50 \mathrm{mM}$ Tris- $\mathrm{HCl}$, $10 \mathrm{mM} \mathrm{MgCl}_{2}$, and $2 \mathrm{mM} \mathrm{EGTA}, \mathrm{pH} 7.2$ ) and centrifuged at $38,000 \mathrm{~g}$ for $10 \mathrm{~min}$. The pellets were suspended to a final concentration of 40 $\mathrm{mg}$ tissue wet weight $/ \mathrm{ml}$ in homogenization buffer. $100 \mu \mathrm{l}$ of the membrane preparation was added to a $1.5-\mathrm{ml}$ polypropylene microtube containing $100 \mu \mathrm{l}$ of a rat/human CRH solution ( 12 concentrations ranging from 0 to $1 \mu \mathrm{M})$ and $100 \mu \mathrm{l}$ of ${ }^{125} \mathrm{I}-\mathrm{oCRH}(0.2 \mathrm{nM}$ final concentration) in incubation buffer ( $50 \mathrm{mM}$ Tris- $\mathrm{HCl}, 10 \mathrm{mM} \mathrm{MgCl}_{2}, 2 \mathrm{mM}$ EGTA, $0.15 \%$ bovine serum albumin, 100 kallikrein inhibitor $\mathrm{U} / \mathrm{ml}$ aprotinin, $0.15 \mathrm{mM}$ bacitracin, $\mathrm{pH} 7.2$ ). The reaction was allowed to proceed for $2 \mathrm{~h}$ at room temperature. The tissue was separated from the incubation medium by centrifugation in a microfuge for $8 \mathrm{~min}$ at $12,000 \mathrm{~g}$. The supernatant was aspirated, the pellets washed gently with $1 \mathrm{ml}$ of PBS containing $0.01 \%$ Triton X-100, and the radioactivity of the pellet was measured in a $\gamma$ counter. It has been previously determined that protease and enzyme inhibitors used to prevent CRH receptor degradation do not themselves bind CRH (42). The final protein concentration was determined using the BCA protein assay (Pierce Chemical Co., Rockford, IL). The ${ }^{125}$ I-oCRH-binding data were analyzed by the Macintosh-based nonlinear least-squares curve-fitting computer program LIGAND (43).

\section{Results}

CRH immunostaining in SCW-injected rats. Euthymic LEW/ $\mathrm{N}$ and congenitally athymic LEW.rnu/rnu, but not relatively arthritis-resistant $\mathrm{F} 344 / \mathrm{N}$, rats develop erythema and swelling of peripheral joints within $24 \mathrm{~h}$ after injection of SCW $(6,34$, 44). The acute phase of SCW-induced polyarthritis increases to a maximum at $3 \mathrm{~d}$, and then gradually subsides. Euthymic LEW/N, but not athymic LEW.rnu/rnu or F344/N, rats go on to develop $\mathrm{T}$ cell-dependent chronic polyarthritis that reaches maximum severity by $28 \mathrm{~d}$ after SCW injection. Histologically, the acute polyarthritis is characterized by edema, deposition of fibrin in the synovia and joint space, and infiltration by granulocytes and macrophages. In the chronic phase of SCW-induced arthritis, there is marked synovial connective tissue cell

Table I. CRH Expression in SCW-injected Rats

\begin{tabular}{|c|c|c|c|c|c|c|c|c|c|}
\hline & \multicolumn{3}{|c|}{ Day 0} & \multicolumn{3}{|c|}{ Day 3} & \multicolumn{3}{|c|}{ Day 28} \\
\hline & LEW/N & LEW.rnu/rnu & $\mathrm{F} 344 / \mathrm{N}$ & LEW/N & LEW.rnu/rnu & $\mathrm{F} 344 / \mathrm{N}$ & LEW/N & LEW.rnu/rnu & $\mathrm{F} 344 / \mathrm{N}$ \\
\hline Epidermis & $0-0.5+$ & $1+$ & $0-0.5+$ & $3-4+$ & $3-4+$ & $0-0.5+$ & $4+$ & $1+$ & $0.5+$ \\
\hline \multicolumn{10}{|l|}{ Synovium } \\
\hline Lining cell layer & 0 & 0 & 0 & $3-4+$ & $3+$ & 0 & $3-4+$ & $0-1+$ & 0 \\
\hline Vascular endothelium & 0 & 0 & 0 & $3-4+$ & $3+$ & 0 & $3-4+$ & $0-0.5+$ & 0 \\
\hline Mononuclear inflammatory cells & $\mathrm{NP}^{*}$ & NP & NP & $3-4+$ & $3-4+$ & $0.5-1+$ & $3-4+$ & NP & NP \\
\hline Stromal fibroblast-like cells & 0 & 0 & 0 & $3-4+$ & $3-4+$ & $0+$ & $3-4+$ & $0-0.5+$ & 0 \\
\hline Cartilage chondrocytes & $0-0.5+$ & $0-0.5+$ & $0-0.5+$ & $2-3+$ & $2-3+$ & $0-1+$ & $3-4+$ & $0-0.5+$ & $0-0.5+$ \\
\hline Subchondral bone & $0.5+$ & $0-0.5+$ & $0-0.5+$ & $2-3+$ & $2+$ & $0-1+$ & $3-4+$ & $0-0.5+$ & $0-0.5+$ \\
\hline Bone marrow & $1+$ & $1+$ & $1+$ & $3-4+$ & $3-4+$ & $1+$ & $3-4+$ & $1+$ & $1+$ \\
\hline
\end{tabular}

Graded $0-4+$ on coded slides by a blinded observer. 0 , no staining, $4+$, maximal intensity. ${ }^{*}$ NP, not present. 

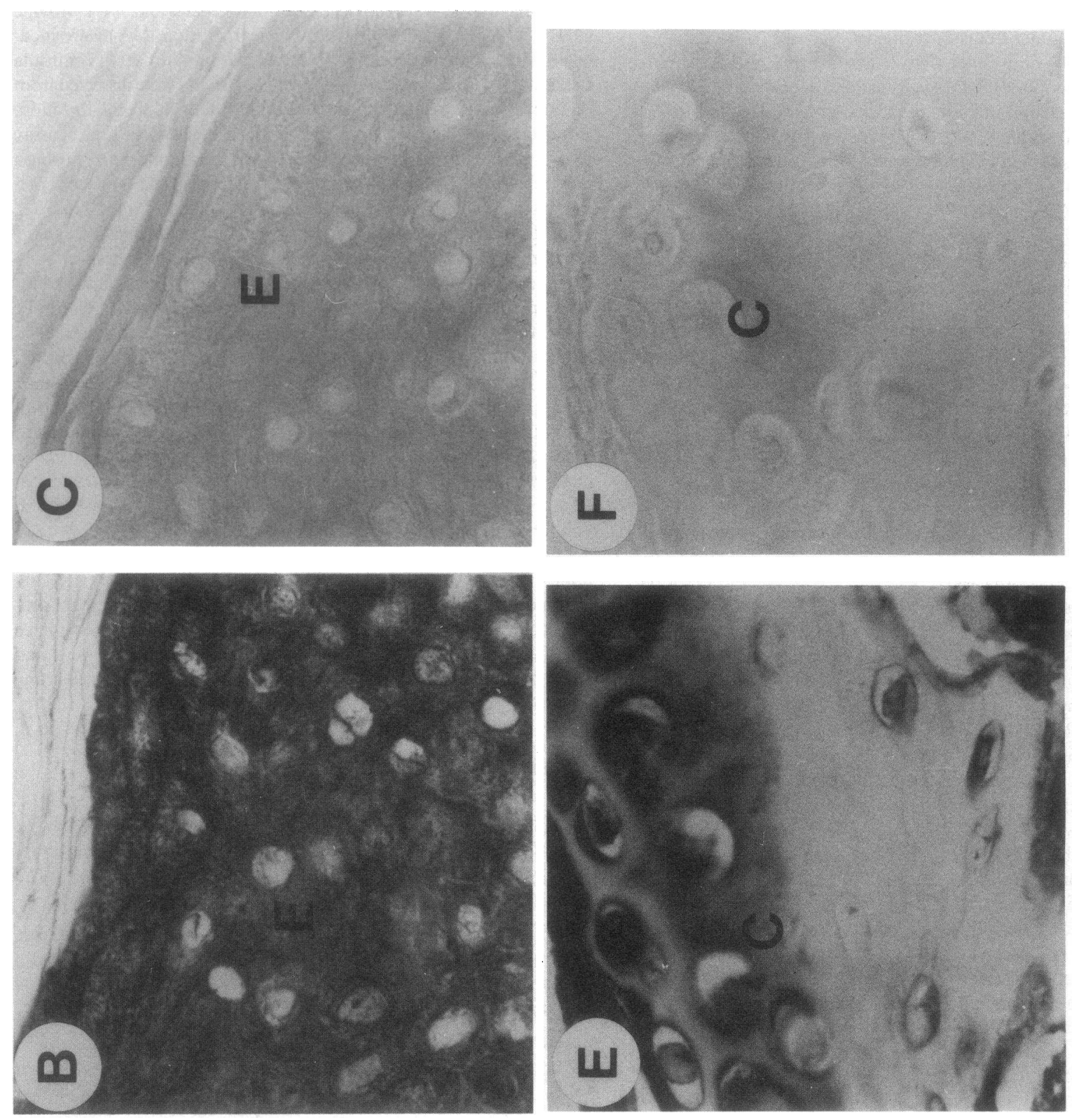

总产总要 空

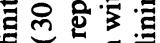
挐

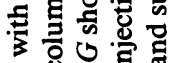
उ० 0

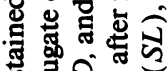

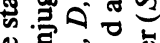
空

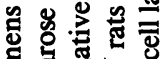

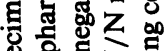
政 की है 영 몽 क 당 ㄷํㅇํㅇ

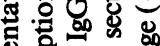

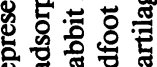

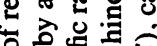

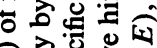

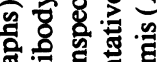
品음 웛 융 蛋

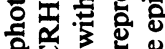

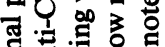
站寻需

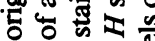

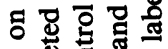
뜽혀 ปั 气 을 을 实正 융 뭉 以

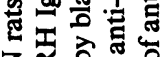
Z兄 。

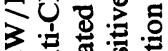
岃氙总 过

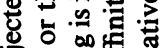
寻次氜

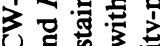
凹 论送电 बैज ह क्ष

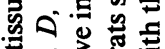

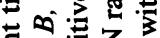

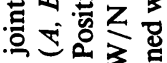

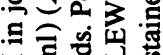

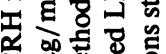

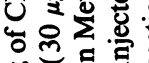
足.

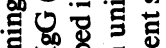

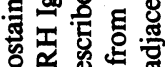
웡 웡

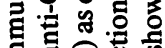
트웛

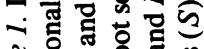
ธ융 速

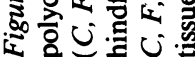



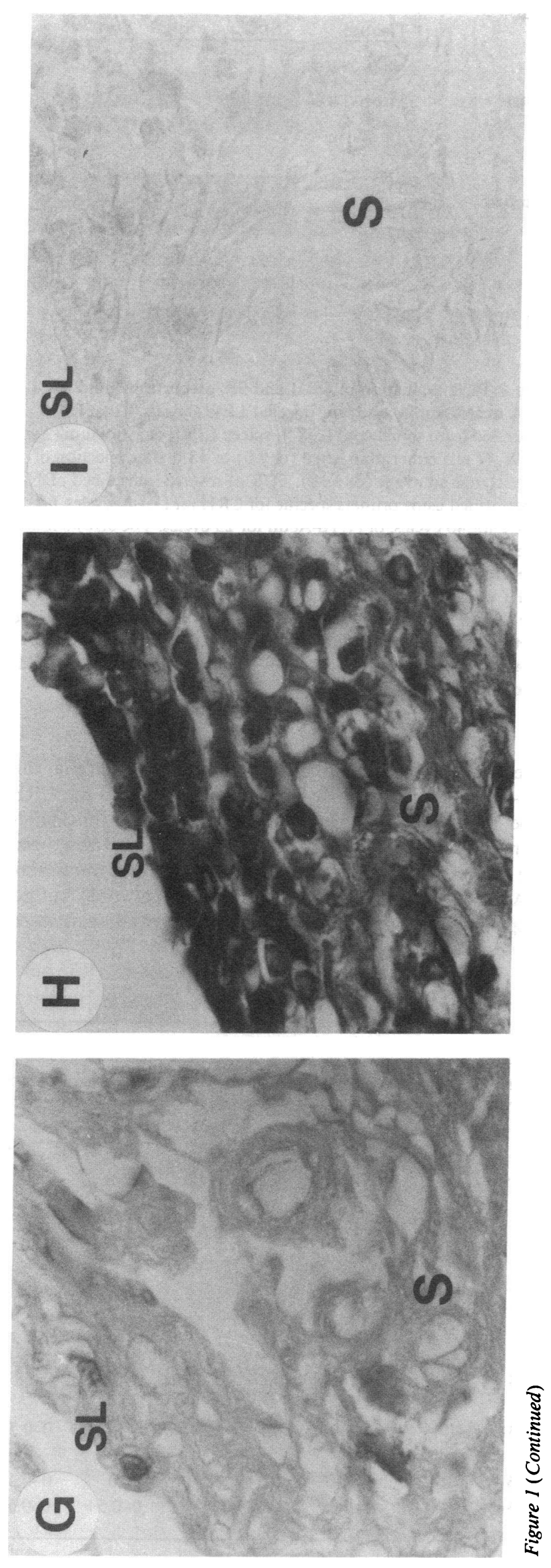

proliferation with villus formation, angiogenesis, infiltration of the synovial tissue by lymphocytes and macrophages, and erosion of marginal cartilage and bone $(34,44)$. There is also increased expression of biochemical markers, such as class II major histocompatibility antigens, transin/stromelysin, heparin-binding growth factor-1, and cyclooxygenase, which parallels histologic inflammation $(36-38,44)$.

Except for low grade staining in the bone marrow, hindfoot specimens from uninjected rats showed little CRH immunoreactivity in any rat strain (Table I and Fig. $1, A, D$, and $G$ ). However, by day 3 after SCW injection, CRH immunostaining increased markedly in euthymic LEW/N and athymic LEW.rnu/rnu rats, but not F344/N rats (Table I). iCRH was present in many different sites, including the epidermis, synovium (lining cell layer, vascular endothelium, mononuclear inflammatory cells, and stromal fibroblast-like cells), cartilage chondrocytes, subchondral bone, and bone marrow. At day 28 after injection of SCW, euthymic LEW/N rats expressed high levels of iCRH (Table I and Fig. $1, B, E$, and $H$ ) in joints and surrounding tissues, whereas athymic LEW.rnu/rnu and F344/ $\mathrm{N}$ rats were not different from control animals. Immunostaining with nonspecific rabbit IgG (data not shown) or anti-CRH antibody depleted by adsorption on CRH-Sepharose (Fig. 1, $C, F$, and $I$ ) was uniformly negative.

Effects of dexamethasone on CRH immunostaining in acute $S C W$-induced arthritis. We treated LEW/N rats with twice daily injections of dexamethasone or PBS beginning on the day of SCW injection to assess the effect of glucocorticoids on iCRH expression in acute SCW-induced arthritis. We observed a dose-dependent decrease in the extent and intensity of CRH immunoreactivity after dexamethasone treatment ( Table II ) $10 \mu \mathrm{g} / \mathrm{d}$ of dexamethasone abolished infiltration of synovium with monuclear inflammatory cells, yet intermediategrade CRH immunoreactivity clearly remained in the epidermis, the synovial lining cell layer, the vascular endothelium, the stromal fibroblast-like cells, subchondral bone, and bone marrow.

CRH immunostaining in adjuvant-injected rats. Chronic destructive polyarthritis develops in susceptible rat strains after intradermal injection of a suspension of heat-killed mycobacteria in oil. Clinical arthritis appears on days 10-12 after adjuvant injection and is dependent on the activation and recruitment of $\mathrm{T}$ lymphocytes. Euthymic LEW/N rats are adjuvant arthritis susceptible, whereas athymic LEW.rnu/rnu do not develop clinically apparent disease. $\mathrm{F} 344 / \mathrm{N}$ rats are usually relatively adjuvant arthritis resistant and develop minimal clinically apparent arthritis. Histologically, LEW/N rats develop perivascular mononuclear cell infiltration and edema that progresses to more intense cellular infiltration, fibrin deposition, proliferation of synovial fibroblasts, pannus formation, and erosion of articular cartilage and periarticular bone $(36,38,45)$.

Hindfoot specimens from LEW/N, LEW.rnu/rnu, and F344/N rats on day 0 (uninjected), and on days 4,10 , and 18 after adjuvant injection were evaluated for $\mathrm{CRH}$ immunoreactivity ( Table III). LEW/N rats showed upregulated iCRH expression beginning on day 4 in the epidermis, synovial lining cell layer, vascular endothelium, stromal fibroblast-like cells, cartilage chondrocytes, subchondral bone, and bone marrow, which occurred before the influx of mononuclear inflammatory cells. CRH immunostaining was further enhanced on days 10 and 18 after adjuvant injection, which paralleled the influx 
Table II. Effect of Dexamethasone on CRH Expression in Acute SCW Arthritis

\begin{tabular}{lccc}
\hline & \multicolumn{3}{c}{ Dose } \\
\cline { 2 - 4 } \multicolumn{1}{c}{ Dexamethasone treatment } & 0 & 1 & 10 \\
\hline & & $\mu g$ & \\
Epidermis & $3-4+$ & $3+$ & $2-3+$ \\
Synovium & & & \\
$\quad$ Lining cell layer & $3-4+$ & $2-3+$ & $2+$ \\
$\quad$ Vascular endothelium & $3+$ & $2-3+$ & $1-2+$ \\
$\quad$ Mononuclear inflammatory cells & $3-4+$ & $2-3+$ & $\mathrm{NP}$ \\
$\quad$ Stromal fibroblast-like cells & $3+$ & $2-3+$ & $1-2+$ \\
Cartilage chondrocytes & $2-3+$ & $1-2+$ & $0.5+$ \\
Subchondral bone & $2-3+$ & $2+$ & $2+$ \\
Bone marrow & $3-4+$ & $3-4+$ & $2+$ \\
& & & \\
\hline
\end{tabular}

Day 3 after injection of SCW. Graded $0-4+$ on coded slides by a blinded observer. 0 , no staining; $4+$, maximal intensity. ${ }^{*} \mathrm{NP}$, not present.

of mononuclear inflammatory cells into the joints and surrounding tissues. Athymic LEW.rnu/rnu rats also showed increased CRH immunoreactivity at day 4 that was not sustained by day 10 after adjuvant injection. Relatively adjuvant arthritis-resistant F344/N rats did not increase CRH immunostaining after injection with adjuvant.

Expression of CRH $m R N A$ in adjuvant-injected rats. $\mathrm{CRH}$ mRNA is known to be expressed in many regions of the brain, including hypothalamus, cerebral cortex, striatum, hippocampus, midbrain, and brainstem. CRH mRNA has also been detected in spinal cord, pituitary, adrenal, and testis (46). We used PCR to evaluate CRH mRNA expression during adjuvant-induced arthritis (Fig. $2 A$ ). Amplification of cDNA with the primers used in this study predicted a fragment of 311

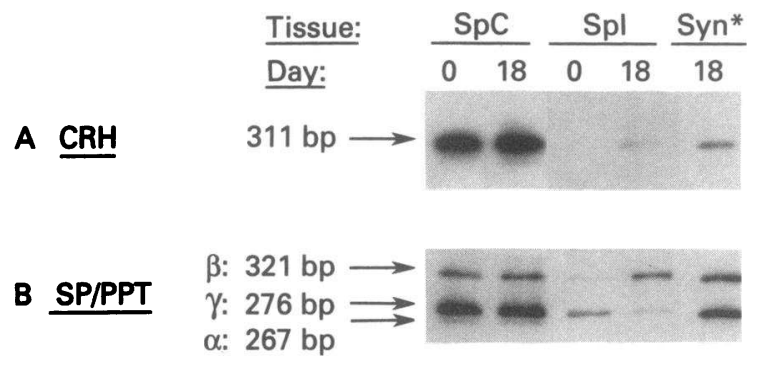

C B Actin

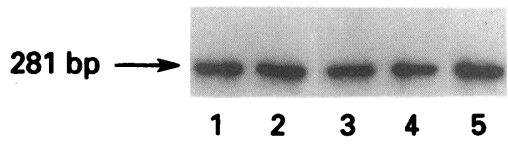

Figure 2. PCR evaluation of CRH and SP/preprotachykinin (PPT) mRNA expression in adjuvant-injected LEW/N rats. Total RNA was purified from spinal cord $(S p C)$, spleen $(S p l)$, or synovium $(S y n)$ of $\mathrm{LEW} / \mathrm{N}$ rats either uninjected (day 0 ) or $18 \mathrm{~d}$ after injection of mycobacterial adjuvant (day 18). PCR of reverse-transcribed cDNA was performed using primers specific for CRH for $(A) 40$ cycles, $(B)$ SP/PPT for 40 cycles, or $(C) \beta$-Actin for 25 cycles. The arrows indicate specific fragments and their sizes in base pairs $(b p)$. The PCR primers for SP/PPT were designed to detect the $\alpha, \beta$, and $\gamma$ forms of the PPT mRNA. Negative controls performed with no RNA added to the reverse transcription reaction or no reverse transcriptase yielded no detectable fragments with any primer pairs. *RNA from synovia of nonarthritic rats was not analyzed because sufficient tissue could not be obtained.

nucleotides in length. Southern blot analysis showed that this PCR-generated fragment hybridized specifically to the CRH probe, thereby confirming the specificity of the 311-nucleotide fragment (data not shown). Fragments of the predicted size were easily detected after amplification of reverse-transcribed RNA for $\mathbf{4 0}$ temperature cycles from the spinal cords, but not the spleens, of control animals. On day 18 after adjuvant injec-

Table III. CRH Expression in Adjuvant-injected Rats

\begin{tabular}{|c|c|c|c|c|c|c|c|c|c|c|c|c|}
\hline & \multicolumn{3}{|c|}{ Day 0} & \multicolumn{3}{|c|}{ Day 4} & \multicolumn{3}{|c|}{ Day 10} & \multicolumn{3}{|c|}{ Day 18} \\
\hline & LEW/N & LEW.rnu/rnu & F344/N & LEW/N & LEW.rnu/rnu & F344/N & LEW/N & LEW.rnu/rnu & F344/N & LEW/N & LEW.rnu/rnu & F344/N \\
\hline $\begin{array}{l}\text { Epidermis } \\
\text { Synovium }\end{array}$ & $0-0.5+$ & $1+$ & $0-0.5+$ & $2+$ & $2+$ & $0.5+$ & $2-3+$ & $0.5-1+$ & $0-1+$ & $2-3+$ & $0-0.5+$ & $0-0.5+$ \\
\hline $\begin{array}{l}\text { Lining cell layer } \\
\text { Vascular }\end{array}$ & 0 & 0 & 0 & $1+$ & $2+$ & $0-0.5+$ & $2+$ & $0.5-1+$ & $0-0.5+$ & $2-3+$ & 0 & $0-0.5+$ \\
\hline $\begin{array}{l}\text { endothelium } \\
\text { Mononuclear } \\
\text { inflammatory }\end{array}$ & 0 & 0 & 0 & $1-2+$ & $2+$ & 0 & $2+$ & $0-1+$ & $0-0.5+$ & $2-3+$ & 0 & 0 \\
\hline $\begin{array}{l}\text { cells } \\
\text { Stromal } \\
\text { fibroblast-like }\end{array}$ & NP* & NP & NP & NP & NP & NP & $2+$ & NP & NP & $3+$ & NP & NP \\
\hline cells & 0 & 0 & 0 & $1-2+$ & $1-2+$ & $0-0.5+$ & $2-3+$ & $0-1+$ & $0-0.5+$ & $3-4+$ & $0-0.5+$ & $0-0.5+$ \\
\hline $\begin{array}{l}\text { Cartilage } \\
\text { chondrocytes }\end{array}$ & $0-0.5+$ & $0-0.5+$ & $0-0.5+$ & $1-2+$ & $2+$ & $0-0.5+$ & $2-3+$ & $0-1+$ & $0-0.5+$ & $2+$ & $0-0.5+$ & $0-0.5+$ \\
\hline $\begin{array}{l}\text { Subchondral } \\
\text { bone }\end{array}$ & $0.5+$ & $0-0.5+$ & $0-0.5+$ & $1+$ & $1-2+$ & $0-0.5+$ & $1-2+$ & $0-1+$ & $0-0.5+$ & $2+$ & 0 & $0-0.5+$ \\
\hline Bone Marrow & $1+$ & $1+$ & $1+$ & $1-2+$ & $2+$ & $0-0.5+$ & $1-2+$ & $0-1+$ & $0-0.5+$ & $2+$ & $0-0.5+$ & $0-0.5+$ \\
\hline
\end{tabular}

Graded 0-4+ on coded slides by a blinded observer. 0 , no staining, 4+, maximal intensity. ${ }^{*}$ NP, not present. 


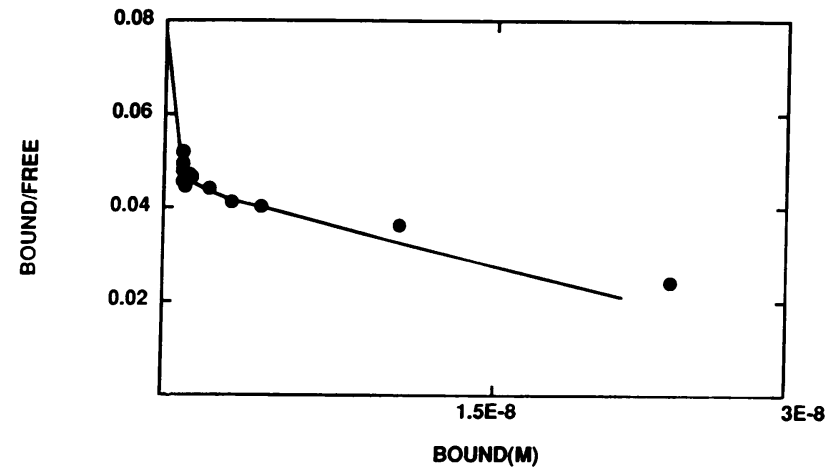

Figure 3. Scatchard plot of competitive displacement binding of ${ }^{125} \mathrm{I}$ oCRH in synovial tissue of adjuvant-arthritic rats. Synovial homogenate preparations were incubated in the presence of ${ }^{125} \mathrm{I}-\mathrm{oCRH}$ and increasing concentrations of rat/human $\mathrm{CRH}$ as described in Methods. Simultaneous Scatchard analysis of binding curves $(n=3)$ using the computer program LIGAND revealed high and low affinity binding sites. The apparent $K_{\mathrm{d}}$ values were 3.4 and $933 \mathrm{nM}$ corresponding to $B_{\max }$ values of $2.7 \times 10^{-11}$ and $4.1 \times 10^{-8} \mathrm{M}$, respectively. The amount of tissue added to each tube represented $16.4 \pm 3.3 \mathrm{mg}$ of protein.

tion, which is the time of maximally severe arthritis, fragments of the predicted size were detected in synovia and spleens, as well as spinal cords.

CRH equilibrium binding characteristics of rat adjuvant arthritic synovia. Equilibrium binding of ${ }^{125} \mathrm{I}$-oCRH was measured in homogenates of rat synovial tissues collected on day 18 after adjuvant injection using assay conditions identical to those described for membrane preparations from mouse spleens (47). When increasing concentrations of the synovial tissue homogenates were incubated with ${ }^{125} \mathrm{I}$-oCRH, specific binding of radiolabeled oCRH was linear with increasing tissue concentration. Competitive displacement curves of ${ }^{125} \mathrm{I}$-oCRH binding in rat synovial homogenates incubated with increasing concentrations of rat/human $\mathrm{CRH}$ demonstrated that the specific binding was saturable. Saturation analysis of ${ }^{125} \mathrm{I}-\mathrm{oCRH}$ binding in these displacement curves revealed a curvilinear Scatchard plot, suggesting the presence of multiple binding sites (Fig. 3). Simultaneous analysis of these Scatchard plot data using the nonlinear curve-fitting program LIGAND suggested that the data best fit a two-site rather than a single-site model, although this difference did not reach statistical significance $(P=0.076)$. The $K_{\mathrm{d}}$ for the one-site model was $432 \mathrm{nM}$ with $\mathrm{a} \mathrm{B}_{\max }$ of $319 \mathrm{pmol} / \mathrm{mg}$ protein. In the two-site model, the $K_{\mathrm{d}}$ values of 3.4 and $933 \mathrm{nM}$ corresponded to $\mathrm{B}_{\max }$ values of $506 \mathrm{fmol} / \mathrm{mg}$ protein and $768 \mathrm{pmol} / \mathrm{mg}$ protein, respectively.

Immunostaining of SP in SCW-and adjuvant-injected rats. The extent and intensity of immunostaining for SP paralleled the immunostaining for CRH in LEW/N rats, both in SCW-injected (Fig. 4) and adjuvant-injected rats (data not shown). The tissue localization of SP was also very similar to that of iCRH.

Expression of SP (preprotachykinin) $m R N A$ in adjuvantinjected rats. SP is a member of the tachykinin family of neuropeptides that is generated by posttranslational processing of preprotachykinin (PPT) mRNA. Three different alternatively spliced mRNAs are generated from a single gene. $\alpha$-PPT mRNA is processed only to SP, whereas $\beta$-PPT mRNA can be processed to SP, neurokinin A, or neurokinin K; and $\gamma$-PPT can be a precursor for SP, neurokinin A, or neuropeptide $\gamma$ (40). Fragments of the expected sizes for the $\alpha, \beta$, and $\gamma$ forms of PPT mRNA were easily detectable in control spinal cord and in day 18 adjuvant-injected spinal cord and were also de-
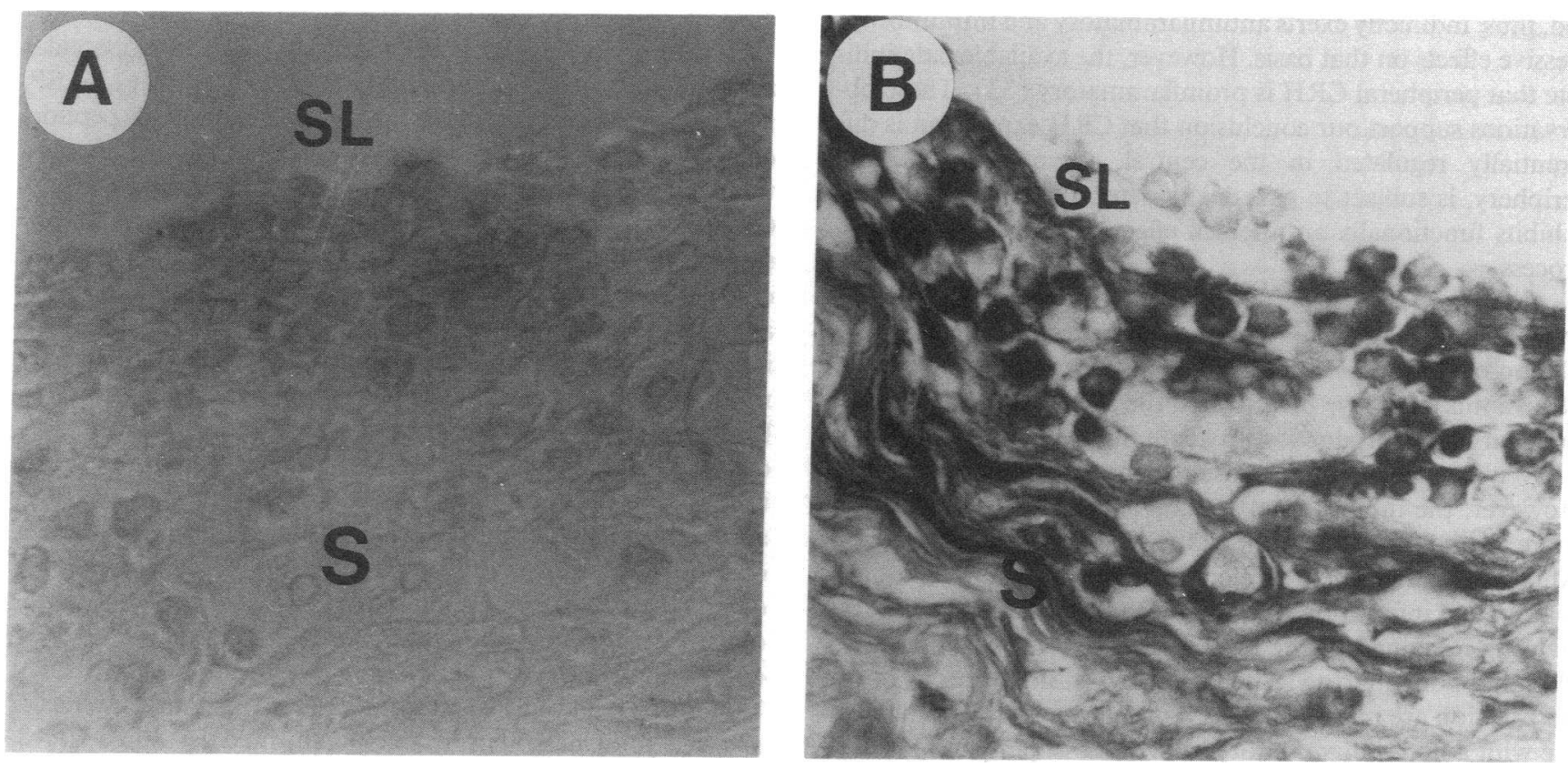

Figure 4. Immunostaining of SP in joint tissues of SCW-injected LEW/N rats. Sections ( $250 \times$ on original photographs) of representative hindfoot specimens of $(A)$ uninjected $\mathrm{LEW} / \mathrm{N}$ rats or $(B) \mathrm{LEW} / \mathrm{N}$ rats $28 \mathrm{~d}$ after injection of streptococcal cell walls stained with affinity-purified polyclonal anti-SP antibody $(30 \mu \mathrm{g} / \mathrm{ml})$. Positive staining is indicated by black deposits. Control staining with anti-SP IgG previously adsorbed with SP-Sepharose conjugate or normal rabbit IgG was uniformly negative. The labels indicate synovial lining cell layer $(S L)$ and sublining synovial tissues $(S)$. 
tectable in synovium from adjuvant-arthritic rats (Fig. $2 \mathrm{~B}$ ). The relative abundance of the PPT mRNA forms in the spinal cord was $\gamma>\beta \gg \alpha$, consistent with previous reports for rat nervous tissues (40). We showed a similar pattern of mRNA forms in synovial tissue. In spleen there were differences in the relative abundance of the $\beta$ and $\gamma$ forms in control and adjuvant-arthritic rats, the significance of which is unknown, and the $\alpha$ form was not detected (Fig. $2 B$ ).

\section{Discussion}

Immunoreactive $\mathrm{CRH}$ expression was markedly increased in the joints and surrounding tissues of rats with acute and chronic SCW-induced and adjuvant-induced arthritis. The extent and intensity of $\mathrm{CRH}$ immunoreactivity generally paralleled the severity of the inflammatory response. There were striking strain differences in the local expression of iCRH. Arthritis-susceptible euthymic LEW/N rats exhibited high levels of iCRH expression in both acute and chronic SCW-induced and adjuvant-induced arthritis, whereas $\mathrm{F} 344 / \mathrm{N}$ rats had no such increases in response to either SCW or adjuvant. Congenitally athymic LEW.rnu/rnu rats developed increased iCRH on day 3 after SCW injection that returned to baseline levels by day 28 , indicating that $\mathrm{T}$ cells are required for sustained high level CRH expression in the joints. In contrast to local iCRH, we have previously shown that $\mathrm{iCRH}$ production in the hypothalamus is blunted in LEW/N rats in response to numerous stimuli, including SCW, whereas F344/N rats show marked increases in hypothalamic $\mathrm{iCRH}$ production in response to the same stimuli (1-5). To summarize, arthritis-susceptible LEW/ $\mathrm{N}$ rats have a deficient hypothalamic $\mathrm{CRH}$ response to inflammatory stimuli but express high levels of $\mathrm{iCRH}$ in inflammatory sites, whereas $\mathrm{F} 344 / \mathrm{N}$ rats exhibit the opposite $\mathrm{CRH}$ responses. Hypothalamic CRH influences glucocorticoid levels and, thus, indirectly exerts antiinflammatory and immunosuppressive effects on that basis. However, the available data indicate that peripheral CRH is proinflammatory (33). These observations support our conclusion that $\mathrm{CRH}$ expression is differentially regulated in the central nervous system and periphery, is subject to genetically determined variation, and exhibits functionally antithetical effects on the inflammatory process.

Glucocorticoids are known to exert negative feedback on hypothalamic $\mathrm{CRH}$-containing neurons, resulting in downregulation of CRH mRNA and decreased secretion of CRH (41, 48). In this study, we investigated the effect of dexamethasone on local iCRH production in acute SCW-induced arthritis in LEW/N rats and found a dose-dependent decrease of iCRH. However, the inhibition of mononuclear cell infiltration was more pronounced than the inhibition of iCRH expression. After dexamethasone treatment sufficient to eliminate inflammatory cell infiltration of the joints, clear-cut CRH immunostaining remained in the skin, synovium, cartilage, and subchondral bone marrow. The physiological implications of this observation are not clear at the present time, but it is compatible with a non-inflammatory cell source of peripheral iCRH.

There is evidence, however, that inflammatory cells may synthesize CRH. CRH mRNA is detectable by Northern analysis of relatively large amounts of poly (A) ${ }^{+}$RNA (25 $\left.\mu \mathrm{g}\right)$ from peripheral blood leukocytes of normal humans (27). We also detected a CRH-specific fragment, by PCR amplification of reverse-transcribed RNA from the synovia and spleens from adjuvant arthritic LEW/N rats. The specific cells that synthesize CRH at the inflammatory site are not yet certain, but our results combined with previous observations suggest that infiltrating mononuclear cells may be one source of $\mathrm{CRH}$ synthesis within the inflammatory site. CRH mRNA was also found in the spinal cord of control and adjuvant-arthritic LEW/N rats. These data, along with the incomplete inhibition of $\mathrm{ICRH}$ expression by dexamethasone and the presence of iCRH on day 4 after adjuvant injection before the influx of mononuclear inflammatory cells, are consistent with the hypothesis that, analogous to SP, iCRH is also synthesized and released by the peripheral nervous system.

In the present study, we have identified specific CRH-binding sites in adjuvant-arthritic rat synovial tissues. ${ }^{125} \mathrm{I}-\mathrm{oCRH}$ binding was saturable and increased linearly with increasing protein concentration. In agreement with previous findings in mouse spleen (47), Scatchard analysis of competitive displacement curves suggested the presence of high and low affinity binding sites for $\mathrm{CRH}$ in rat synovial tissue. The high affinity binding site $\left(K_{\mathrm{d}}=3.4 \mathrm{nM}\right)$ in rat synovial tissue corresponded to the high affinity binding site for $\mathrm{CRH}$ previously identified in mouse spleen (47) and brain (42). The low affinity binding site $\left(K_{d}=933 \mathrm{nM}\right)$, corresponding to a high $\mathrm{B}_{\max }$ value of 768 $\mathrm{pmol} / \mathrm{mg}$ protein, represents a high capacity binding site, which might function to retain relatively high concentrations of CRH in inflamed joint tissues. We previously demonstrated that despite relatively high concentrations of $\mathrm{iCRH}$ present in an inflammatory site, there was no increase in the concentration of plasma CRH (33). Further studies are necessary to determine whether the high concentrations of $\mathrm{CRH}$ present in inflamed tissue exert a regulatory role on CRH-binding affinity or capacity in the specific cell type(s) expressing CRH receptors. These data provide further evidence that support our view that $\mathrm{CRH}$ has a local physiological role in inflammatory joint diseases.

Other peripheral nervous system-derived neuropeptides are thought to influence the inflammatory process (12). SP, neurokinin A, somatostatin, vasoactive intestinal peptide, cholecystokinin, and calcitonin gene-related peptide are peptide products of capsaicin-sensitive sensory afferent fibers. CRH is also depleted in the rat spinal cord in response to capsaicin (19). Much attention has been focused on SP, which can evoke many signs of acute inflammation and inflammatory arthritis, including vasodilation, increased vascular permeability, $T$ lymphocyte proliferation, mast cell degranulation, macrophage activation, granulocyte activation and chemotaxis, fibroblast proliferation, and synoviocyte secretion of prostaglandin $E_{2}$ and collagenase $(14,18,49-54)$. SP-containing nerve terminals have been demonstrated in normal rat synovium but are not detectable in the superficial lining and sublining zones of synovium from adjuvant-arthritic rats (55). This finding could be explained by depletion of peptidergic nerve terminals of their neuropeptide content. Alternatively, hyperplastic synovium of arthritic joints could outgrow its nerve supply (55). Direct injection of SP significantly augments radiographically assessed joint destruction in adjuvant-induced arthritis (18, 56 ), and inflammation in the rat knee joint induced by carrageenin can be inhibited by SP antagonists (16). We observed immunoreactive SP in the synovia and surrounding tissues of $\mathrm{LEW} / \mathrm{N}$ rats with arthritis in a distribution that paralleled to iCRH. SP (preprotachykinin) mRNA was easily detectable in 
spinal cords, but also in synovial tissues from adjuvant arthritic rats, suggesting that $\mathrm{SP}$ is also synthesized locally.

In addition to the peripheral sensory afferent system, the sympathetic efferent system also contributes to the inflammatory process in adjuvant-induced arthritis (57). Corderre and colleagues ( 58 ) showed that chemical sympathectomy with 6 hydroxydopamine markedly reduces the radiologically assessed joint destruction of adjuvant-induced arthritis. Therefore, sympathetic system-derived or -dependent proinflammatory substances may play a role in tissue destruction. Immunoreactive CRH is present in the interomediolateral sympathetic column, particularly in the thoracic and lumbar segments of the spinal cord (22), as well as in the ganglia of the sympathetic chain $(23,24)$, and our work suggests that locally secreted CRH may play a role in the pathological process of adjuvant-induced arthritis. Further studies are needed to evaluate the relative contributions of $\mathrm{CRH}$ delivered to the joints by the peripheral nervous system and $\mathrm{CRH}$ that is synthesized locally in joint tissues.

In summary, these data provide support for our view that CRH is not only a major regulator of the HPA axis but also directly involved in the inflammatory process. There is markedly increased $\mathrm{iCRH}$ in carrageenin-induced acutely inflamed tissue (33), acute and chronic SCW-induced arthritis and adjuvant-induced arthritis. Specific CRH-binding activity is present in inflamed synovial tissue from adjuvant-arthritic rats. Additionally, CRH mRNA is synthesized in synovia from arthritic rats, but $\mathrm{CRH}$ may also be delivered to the joint by peripheral nerves. CRH appears to be a multifunctional neuropeptide regulator of inflammation, whose expression and effects are site specific.

\section{Acknowledgments}

We are grateful to Dr. Joseph A. Majzoub for the gift of the plasmid pBSrCRH1300 and George Poy for oligonucleotide synthesis. We would like to express our appreciation to Drs. Elaine F. Remmers and Joseph M. Cash for critical review of the manuscript.

Elizabeth L. Webster has been supported by the pharmacology research associate program (PRAT fellowship) of the National Institute of General Medical Sciences.

\section{References}

1. Sternberg, E. M., J. M. Hill, G. P. Chrousos, T. Kamilaris, S. J. Listwak, P. W. Gold, and R. L. Wilder. 1989. Inflammatory mediator-induced hypothalamic-pituitary-adrenal axis activation is defective in streptococcal cell wall arthritis-susceptible Lewis rats. Proc. Natl. Acad. Sci. USA. 86:2374-2378.

2. Sternberg, E. M., W. S. Young III, R. Bernardini, A. E. Calogero, G. P. Chrousos, P. W. Gold, and R. L. Wilder. 1989. A central nervous system defect in biosynthesis of corticotropin-releasing hormone is associated with susceptibility to streptococcal cell wall-induced arthritis in Lewis rats. Proc. Natl. Acad. Sci. USA. 86:4771-4775.

3. Calogero, A. E., E. M. Sternberg, G. Bagdy, C. Smith, R. Bernardini, S. Aksentijevich, R. L. Wilder, P. W. Gold, and G. P. Chrousos. 1992. Neurotransmitter-induced hypothalamic-pituitary-adrenal axis responsiveness in inflammatory disease-susceptible Lewis rats: in vivo and in vitro studies suggesting a global defect in CRH secretion. Neuroendocrinology. 55:600-608.

4. Aksentijevich, S., H. J. Whitfield, Jr, W. S. Young III, R. L. Wilder, G. P. Chrousos, P. W. Gold, and E. S. Sternberg. 1992. Arthritis-susceptible Lewis rats fail to emerge from the stress hyporesponsive period. Dev. Brain Res. 65:115118.

5. Sternberg, E. M., J. R. Glowa, M. A. Smith, A. E. Calogero, S. J. Listwak, S. Aksentijevich, G. P. Chrousos, R. L. Wilder, and P. W. Gold. 1992. Corticotropin releasing hormone related behavioral and neuroendocrine responses to stress in Lewis and Fischer rats. Brain Res. 570:54-60.

6. Wilder, R. L., G. B. Calandra, G. A. J., K. D. Wright, and C. T. Hansen.
1982. Strain and sex variation in the susceptibility to streptococcal cell wall-induced polyarthritis in the rat. Arthritis Rheum. 25:1064-1072.

7. Griffiths, M., and C. DeWitt. 1984. Genetic control of collagen-induced arthritis in rats: the immune response to type II collagen among susceptible and resistant strains and evidence for multiple gene control. J. Immunol. 132:2830 2836.

8. Ben-Nun, A., H. Wekerle, and I. Cohen. 1982. Experimental autoimmune encephalomyelitis (EAE) in genetically resistant rats: PVG rats resist active induction of EAE but are susceptible to and can generate EAE effector T cell lines. J. Immunol. 129:918-919.

9. Vanderbark, A., H. Offner, T. Reshef, R. Fritz, C.-H. Chou, and I. Cohen. 1985. Specificity of T lymphocyte lines for peptides of myelin basic protein. $J$ Immunol. 135:229-233.

10. Caspi, R., R. Wilder, F. Roberge, C. Chan, W. Leake, H. C. T., and R. Nussenblatt. 1989. Studies of EAU induction in different rat strains compatible in RT1. Invest. Ophthalmol. Visual Sci. 30(Suppl.):81. (Abstr.)

11. Herbort, C. P., C. C. Chan, and R. B. Nussenblatt. 1990. Endotoxin-induced uveitis in the rat: a hypothesis for preferential involvement of the anterior uvea. Curr. Eye Res. 9(Suppl.):119-124.

12. Payan, D. G., J. P. McGillis, and E. J. Goetzl. 1986. Neuroimmunology. Adv. Immunol. 39:299-323.

13. Colpaert, F. C., J. Donnerer, and F. Lembeck. 1983. Effects of capsaicin on inflammation and on the substance $P$ content of nervous tissues in rats with adjuvant arthritis. Life Sci. 32:1827-1834.

14. Saria, A. 1984. Substance $P$ in sensory nerve fibers contributes to the development of oedema in the rat hind paw after thermal injury. Br. J. Pharmacol. 8:217-222.

15. Lam, F. Y., and W. R. Ferrell. 1989. Capsaicin suppresses substance P-induced joint inflammation in the rat. Neurosci. Lett. 105:155-158.

16. Lam, F. Y., and W. R. Ferrell. 1989. Inhibition of carrageenan-induced joint inflammation by substance P antagonist. Ann. Rheum. Dis. 48:928-932.

17. Jancso, N., A. Jancso-Gabor, and J. Szolcsanyi. 1967. Direct evidence for neurogenic inflammation and its prevention by denervation and by pretreatment with capsaicin. Br. J. Pharmacol. 85:138-151.

18. Basbaum, A. I., and J. D. Levine. 1990. The contribution of the nervous system to inflammation and inflammatory disease. Can. J. Physiol. Pharmacol. 69:647-651.

19. Skofitsch, G., G. S. Hamill, and D. M. Jacobowitz. 1984. Capsaicin depletes corticotropin-releasing factor-like immunoreactive neurons in the medulla oblongata and spinal cord. Neuroendocrinology. 38:514-517.

20. Levine, J. D., S. J. Dardick, M. F. Roizen, C. Helms, and A. I. Basbaum. 1986. Contribution of sensory afferents and sympathetic efferents to joint injury in experimental arthritis. J. Neurosci. 6:3423-3429.

21. Coderre, T. J., A. I. Basbaum, and J. D. Levine. 1989. Neural control of vascular permeability: interactions between primary afferents, mast cells, and sympathetic efferents. J. Neurophysiol. (Bethesda). 62:48-58.

22. Merchenthaler, I., M. A. Hynes, S., Vingh, A. V. Schally, and P. Petrusz. 1983. Immunocytochemical localization of corticotropin releasing factor (CRF) in the rat spinal cord. Brain Res. 275:373-377.

23. Suda, T., N. Tomori, F. Tozawa, H. Demura, K. Shizume, T. Mouri, Y. Miura, and N. Sasano. 1984. Immunoreactive corticotropin and corticotropinreleasing factor in human hypothalamus, adrenal, lung cancer, and pheochromocytoma. J. Clin. Endocrinol. \& Metab. 58:919-924.

24. Udelsman, R., J. P. Harwood, M. A. Millan, G. P. Chrousos, D. S. Goldstein, R. Zimlichman, K. J. Catt, and G. Aguilera. 1986. Functional corticotropin releasing factor receptors in the primate peripheral sympathetic nervous system. Nature (Lond.). 319:146-150.

25. Webster, E. L., D. E. Tracey, M. A. Jutila, S. A. Wolfe, and E. B. de Souza 1990. Corticotropin-releasing factor receptors in mouse spleen: identification of receptor-bearing cells as resident macrophages. Endocrinology. 127:440-452.

26. Singh, V. K., and H. H. Fudenberg. 1988. Binding of [ $\left.{ }^{125} \mathrm{I}\right]$ corticotropinreleasing factor to blood immunocytes and its reduction in Alzheimer's disease. Immunol. Lett. 18:5-8.

27. Stephanou, A., D. S. Jessop, R. A. Knight, and S. L. Lightman. 1990. Corticotropin-releasing factor-like immunoreactivity and mRNA in human leukocytes. Brain Behav. Immun. 4:67-73.

28. Singh, V. K. 1989. Stimulatory effect of corticotropin-releasing neurohormone on human lymphocyte proliferation and interleukin-2 receptor expression. J. Neuroimmunol. 23:256-262.

29. McGillis, J. P., A. Park, P. Rubin-Fletter, C. Turck, M. F. Dallman, and D. G. Payan. 1989. Stimulation of rat B-lymphocyte proliferation by corticotropin-releasing factor. J. Neurosci. Res. 23:346-352.

30. Kavelaars, A., R. E. Ballieux, and C. J. Heijnen. 1989. The role of IL-1 in the corticotropin-releasing factor and arginine-vasopressin-induced secretion of immunoreactive $\beta$-endorphin by human peripheral blood mononuclear cells. $J$. Immunol. 142:2338-2342.

31. Singh, V. K., and C. S. J. Leu. 1990. Enhancing effect of corticotropin-releasing neurohormone on the production of interleukin-1 and interleukin-2. Neurosci. Lett. 120:151-154. 
32. Bateman, A., A. Singh, T. Kral, and S. Solomon. 1989. The immune-hypothalamic-pituitary-adrenal axis. Endocr. Rev. 10:92-112.

33. Karalis, K., H. Sano, J. Redwine, S. Listwak, R. L. Wilder, and G. P. Chrousos. 1991. Autocrine or paracrine inflammatory actions of corticotropinreleasing hormone in vivo. Science (Wash. DC). 254:421-423.

34. Wilder, R. L. 1988. Streptococcal cell wall-induced polyarthritis in rats. In CRC Handbook: Animal Models for the Rheumatic Diseases. Vol. I. R. A Greenwald and H. S. Diamond, editors. CRC Press, Inc., Boca Raton, FL. 33-40.

35. Schurmeyer, T. H., P. C. Avgerinos, P. W. Gold, W. T. Gallucci, T. P. Tomai, G. B. Cutler, Jr., D. L. Loriaux, and G. P. Chrousos. 1984. Human corticotropin-releasing factor in man: pharmacokinetic properties and dose-response of plasma adrenocorticotropin and cortisol secretion. J. Clin. Endocrinol. \& Metab. 59:1103-1108.

36. Case, J. P., H. Sano, R. Lafyatis, E. F. Remmers, G. K. Kumkumian, and R. L. Wilder. 1989. Transin/stromelysin expression in the synovium of rats with experimental erosive arthritis. In situ localization and kinetics of expression of the transformation-associated metalloproteinase in euthymic and athymic Lewis rats. J. Clin. Invest. 84:1731-1740.

37. Sano, H., R. Forough, J. A. Maier, J. P. Case, A. Jackson, K. Engleka, T Maciag, and R. L. Wilder. 1990. Detection of high levels of heparin binding growth factor-1 (acidic fibroblast growth factor) in inflammatory arthritic joints. J. Cell Biol. 110:1417-1426.

38. Sano, H., T. Hla, J. A. M. Maier, L. J. Crofford, J. P. Case, T. Maciag, and R. L. Wilder. 1992. In vivo cyclooxygenase expression in synovial tissues of patients with rheumatoid arthritis and osteoarthritis and rats with adjuvant and streptococcal cell wall arthritis. J. Clin. Invest. 89:97-108.

39. Chirgwin, J., S. Przybyla, R. MacDonald, and W. Rutter. 1979. Isolation of biologically active ribonucleic acid from sources enriched in ribonuclease. Biochemistry. 18:5294-5299.

40. Helke, C. J., J. E. Krause, P. W. Mantyh, R. Couture, and M. J. Bannon 1990. Diversity in mammalian tackykinin peptidergic neurons: multiple peptides, receptors, and regulatory mechanisms. FASEB (Fed. Am. Soc. Exp. Biol.) J. 4:1606-1615.

41. Frim, D. M., B. G. Robinson, K. B. Pasieka, and J. A. Majzoub. 1990. Differential regulation of corticotropin-releasing hormone $\mathrm{mRNA}$ in rat brain. Am. J. Physiol. 258:E686-E692.

42. De Souza, E. B. 1987. Corticotropin-releasing factor receptors in the rat central nervous system: characterization and regional distribution. $J$. Neurosci. 7:88-100.

43. Munson, P. J., and D. Rodbard. 1980. LIGAND: a versatile computerized approach for characterization of ligand binding systems. Anal. Biochem. 297:220-239.

44. Wilder, R. L., J. B. Allen, and C. Hansen. 1987. Thymus-dependent and -independent regulation of Ia antigen expression in situ by cells in synovium of rats with streptococcal cell wall-induced arthritis. Differences in site and intensity of expression in euthymic, athymic, and cyclosporin A-treated LEW and F344 rats. J. Clin. Invest. 79:1160-1171.
45. Pearson, C. M., and F. D. Wood. 1959. Studies of polyarthritis and other lesions induced in rats by injection of Mycobacterial adjuvant. I. General clinical and pathologic characteristics and some modifying factors. Arthritis Rheum. 2:440-459.

46. Thompson, R. C., A. F. Seasholtz, J. O. Douglass, and E. Herbert. 1990 Cloning and distribution of expression of the rat corticotropin-releasing factor (CRF) gene. In Corticotropin-Releasing Factor: Basic and Clinical Studies of a Neuropeptide. E. B. De Souza and C. B. Nemeroff, editors. CRC Press, Inc., Boca Raton, FL. 1-12.

47. Webster, E. L., and E. B. De Souza. 1988. Corticotropin-releasing factor receptors in mouse spleen: identification, autoradiographic localization, and regulation by divalent cations and guanine nucleotides. Endocrinology. 122:609-617.

48. Calogero, A. E., W. T. Gallucci, P. W. Gold, and G. P. Chrousos. 1988. Multiple feedback regulatory loops upon rat hypothalamic corticotropin-releasing hormone secretion. J. Clin. Invest. 82:767-774.

49. Mazurek, N., I. Pecht, V. I. Teichburg, and S. Blumberg. 1981. The role of the N-terminal tetrapeptide in the histamine-releasing action of substance $\mathrm{P}$. Neuropharmacology. 20:1025-1027.

50. Payan, D. G., D. R. Brewster, and E. J. Goetzl. 1983. Specific stimulation of human T lymphocytes by substance P. J. Immunol. 131:1613-1615.

51. Nilsson, J., A. M. von Euler, and C. Dalsgaard. 1985. Stimulation of connective tissue cell growth by substance $\mathrm{P}$ and substance $\mathrm{K}$. Nature (Lond.). 315:61-63.

52. Hartung, H., K. Wolters, and K. V. Toyka. 1986. Substance P: binding properties and studies on cellular responses in guinea pig macrophages. $\mathrm{J}$. Immunol. 136:3856-3863.

53. Kolasinski, S. L., K. A. Haines, E. L. Siegel, B. N. Cronstein, and S. B. Abramson. 1992. Neuropeptides and inflammation: a somatostatin analog as a selective antagonist of neutrophil activation by substance P. Arthritis Rheum. 35:369-375

54. Lotz, M., D. A. Carson, and J. H. Vaughan. 1987. Substance P activation of rheumatoid synoviocytes: neural pathway in pathogenesis of arthritis. Science (Wash. DC). 235:893-896.

55. Konttinen, Y. T., R. Rees, M. Hukkanen, M. Gronblad, E. Tolvanen, S. J. Gibson, J. M. Polak, and D. A. Brewerton. 1990. Nerves in inflammatory synovium: immunohistochemical observations on the adjuvant arthritic rat model. $J$. Rheumatol. 17:1586-1591.

56. Levine, J. D., M. A. Moskowitz, and A. I. Basbaum. 1985. The contribution of neurogenic inflammation in experimental arthritis. $J$. Immunol. 135:843S-847S.

57. Coderre, T. J., A. I. Basbaum, M. F. Dallman, C. Helms, and J. D. Levine 1990. Epinephrine exacerbates arthritis by an action at presynaptic beta ${ }_{2}$-adrenoceptors. Neuroscience. 34:521-523.

58. Coderre, T. J., A. K. Chan, C. Helms, A. I. Basbaum, and J. D. Levine 1991. Increasing sympathetic nerve terminal-dependent plasma extravasation correlates with decreased arthritis joint injury in rats. Neuroscience. 40:185-189. 